\title{
6
}

\section{Legal Aid in Iceland}

\author{
Hildur Fjóla Antonsdóttir
}

\section{Introduction}

The aim of this chapter is to give an overview of the public legal aid provision for civil cases in Iceland: how it has developed, and the main issues that appear to have been, and remain, contentious. It is safe to say that the framing of public legal aid in civil cases in Iceland has primarily been in terms of the law. Mostly lawyers have discussed the topic of legal aid and there is little evidence of a socio-legal debate, or even a policy debate on the issue in terms of the broader aims and purposes of legal aid in society, and the social significance of access to justice.

I will begin by giving a brief background to the historical development of legal aid in Iceland. I will then outline the current legislation and administration of legal aid and describe recent discussions in terms of legislative changes on legal aid, against the backdrop of the economic and

I would like to thank Margrét Steinarsdóttir, lawyer and Director of the Icelandic Human Rights Centre, for her helpful comments on this chapter.

H.F. Antonsdóttir $(\bowtie)$

Sociology of Law Department, Lund University, Lund, Sweden

(C) The Author(s) 2018

O. Halvorsen Rønning, O. Hammerslev (eds.), Outsourcing Legal Aid

in the Nordic Welfare States, https://doi.org/10.1007/978-3-319-46684-2_6 
political turmoil that has characterised Icelandic society over the last 10 years. I will then proceed to give an account of the applicants for, and recipients of, legal aid. Following this, I will briefly describe the legal expenses insurance, now found in some of the standard home and family insurance packages offered by the main insurance companies. Finally, I will briefly discuss access to free legal counselling and out-of-court legal assistance services provided by members' organisations and the voluntary sector.

To say that literature on access to legal aid in Iceland is scarce is an understatement. It would seem that only a handful of lawyers have written on the subject over the years, and a few reports have been written on various aspects of legal aid. There have been a few student theses, mostly in law, on the topic, and a number of short articles in Icelandic legal journals. Very little, if any, information on legal aid in Iceland can be found in other languages.

\section{Historical Background to the Development of the Law on Legal Aid}

The first legal provision for free legal assistance in Iceland was included in the procedural rules of the Norwegian and Danish laws that were enacted in Iceland from 1718 to 1732 . The authorities were authorised to appoint a spokesperson to represent, free of charge, poor widows, people with mental health problems, and people without legal guardians. Under a directive from Norway in 1797, new provisions on legal assistance came into force. Their main aim was to assist the poor in claiming their most obvious rights. The eligibility criteria for legal assistance seem to have been very strict, so it was obviously only intended for those who could not provide for themselves (Gíslason 1994).

In 1907, specific laws on legal aid (gjafsókn) came into force, according to which the government was responsible for providing legal aid to churches, hospitals, and institutions that provided support to the poor. Legal aid could also be granted to people who had been certified as poor by the local authorities, or by parish priests. However, before an applicant was granted legal aid, the merits of the case had to be considered, 
although no further guidelines were provided on that point. As before, the law was based on the notion that legal aid was a form of charity (Gíslason 1994).

In 1936, a new law on civil procedure (no. 85/1936) was enacted that included a chapter on legal aid similar to the previous law. This law stipulated that the concept of legal aid (gjafsókn) should apply to both plaintiffs and defendants, and that, before legal aid was granted, the merits of the case should be assessed. The criteria for those who could apply for legal aid were also extended to include schools and municipalities, as well as churches, hospitals, and charities. In special cases, applicants could be granted legal aid if they were in dire straits financially, even if they were not considered poor. In addition to the law on legal aid, there were provisions, in other laws, on people's rights to legal aid under certain circumstances (Gíslason 1994). ${ }^{1}$

No further legislative changes were made to the law on legal aid until the Law on Civil Procedure (no. 91/1991) came into force in 1992, which I will discuss in more detail in the next section. By that time, lawyers and non-lawyers alike had drawn attention to the need for law reform in the area of legal aid (Gíslason 1994). It was pointed out that, due to the increasing complexity of modern societies, there was a greater need for legal information and assistance. It was noted that access to legal aid in the other Nordic countries was considerably more extensive than in Iceland, and that there was a need not only for access to legal aid to pursue court cases, but also for access to legal information and assistance (Eydal 1973; Rafnar 1981).

In 1979, a bill was brought before Parliament that would have established the right to receive necessary legal counselling and assistance outside the court but it was not passed. At the general meeting of the Icelandic Bar Association in 1986, a proposal to expand the provision of legal aid and ensure access to legal aid outside court was accepted. The Minister for Judicial Affairs subsequently appointed a committee charged with drawing up a bill on public legal aid. This bill was brought before Parliament in 1989-1990 and included wider eligibility criteria for legal aid for pursuing cases in court (which the current legislation is based on), together with provisions on the right to general legal information and assistance outside the court in specific cases. However, like the previous 
bill, this one was not enacted (Gíslason 1994). So far, there is still no provision in Icelandic law for legal aid in the form of legal counselling and out-of-court assistance.

\section{The Current Legislation on Legal Aid in Civil Cases and its Administration}

In 1992, the current legislation on legal aid in civil cases came into force with the enactment of the Law on Civil Procedure (no. 91/1991). Chapter XX of this Law, entitled Legal Aid (Gjafsókn), sets out the provisions on legal aid in Articles 125-128, whose contents I will now outline.

The definition of legal aid (gjafsókn) includes legal aid for both plaintiffs and defendants, as was also the case under the previous law. The current law makes the Minister for Judicial Affairs responsible for appointing three lawyers to make up a Legal Aid Committee to review applications and make recommendations on which applicants should be granted legal aid. ${ }^{2}$ While it is the Minister who grants legal aid, he cannot do so unless the Legal Aid Committee has recommended that the application should be funded; however, he has the authority to deny an applicant legal aid, contrary to the recommendations of the Legal Aid Committee. The Minister is also authorised to provide more detailed guidelines on the legal aid eligibility criteria and the workings of the Legal Aid Committee in regulations. ${ }^{3}$

Legal aid is only to be granted if the applicant has sufficient reason to initiate proceedings or defend themselves in civil proceedings, and if one of the following conditions is fulfilled:

A. The applicant's financial situation is such that they could not afford to defend their interests, and the case is of such a nature that it would be considered appropriate that legal aid for it should be financed by public funds,

B. The outcome of the case would have great general significance, or would be of great importance for the employment, social status or other personal status of the applicant. 
The provisions in section $B$ are taken from the previous bill on legal aid that was brought before parliament in 1989-1990. The rationale put forward in the previous bill for this criterion is that it would apply, in particular, when the case involved basic issues concerning legal interpretation, or when it was of significant public interest, or when it had great significance for the socio-economic position of the applicant. In such cases, it could be considered unfair that the applicant should need to bear significant costs.

The state is obliged to pay those costs that the legal aid recipient is responsible for, i.e., the costs of legal services, etc. However, legal aid can be limited to covering only a certain component of the case, or to a certain amount. The lawyer's fees are to be decided by the judge, which means that the state is not obliged to pay the legal costs as charged by the lawyer. The legal aid recipient is exempt from all treasury charges arising from the case, including charges for official certificates and other documents that are a part of the case. The legal aid also covers the enforcement of the recipient's rights, unless otherwise stated in the legal aid licence. Being granted legal aid does not exempt the recipient from paying the legal costs of the other party to the case.

Lawyers are free to set their own fees, and rates can vary between law firms. According to the Icelandic Bar Association's Code of Ethics, lawyers should draw their client's attention to the possibility of legal aid where applicable (The Icelandic Bar Association, n.d.-a). One of the issues that has been raised in relation to fees in legal aid cases is that the amount decided by the judge is often lower than the fees charged by the lawyer, and the decision is not usually accompanied by detailed justification. It has been the norm for lawyers to forgo their legal fees, either entirely, or in part (Magnusson 2005). This arrangement has frequently been criticised by lawyers, who claim that judges do not appreciate the expenses involved in running law firms (Björnsson 2005). This arrangement might mean that lawyers keep their work to a minimum and therefore do not represent their clients in the best way possible, which in effect restricts clients' access to the courts (Jónsson 2005). Another objection is that, due to this arrangement, lawyers will increasingly make special agreements with their clients whereby the clients pay the difference between the fees charged by the lawyer and the amount decided by the 
judge (Særarsson 2005). In 2010, the Judicial Council (dómstólaráð) issued announcement no. 5/2009 stipulating that the hourly rate for legal fees in legal aid cases was 10,000 Icelandic Kronor (ISK) (56€) excluding VAT but the announcement is no longer valid. ${ }^{4}$

It is important to note that, in certain cases, individuals have a legal right to legal aid from the state. Such provisions can be found in various laws. ${ }^{5}$ In a report commissioned by the Icelandic Bar Association on legal aid, this state of affairs has been criticised on the grounds that it is not always clear why legal aid is available in some types of cases but not others. The authors query whether the equality principle is being followed in these circumstances (Jónsson and Harðardóttir 2008). It remains the case, however, that, by law, those who are entitled to legal aid have to submit an application to the Legal Aid Committee.

The regulations issued by the Minister for Judicial Affairs describe in more detail the eligibility criteria for legal aid, and the workings of the Legal Aid Committee. An application to the committee must include the following: the main documents concerning the case; a copy of the applicant's tax returns for the past two years (and the applicant's partner's tax returns, if applicable); information about the applicant's income since the last tax return (and information about the income of the applicant's partner, if applicable); and other relevant documents. The Legal Aid Committee has to be notified if the applicant has an insurance policy that provides legal costs insurance. It is further stipulated that legal aid is only awarded to pursue a case in an Icelandic court, so it is not possibly to apply for legal aid to take legal action in international courts.

The regulations set out in more detail how the law's eligibility criteria should be interpreted. As stated in Article 126 of the Law, the applicant has to have sufficient reason to initiate proceedings, or defend herself or himself in civil proceedings. Furthermore, the case must be of such a nature that it is acceptable for it to be paid for out of public funds; it should be clear that a lawsuit is necessary and that its timing is appropriate; and the case must be likely to be successful. If the case involves a dispute that is already before the courts, in another case that will likely set a precedent, legal aid can be refused until it is possible to see whether the case is likely to succeed. 
The section A criteria allow applications based on the applicant's low economic status. The regulation further stipulates that the annual income criteria for legal aid is 2 million ISK $(12,687 €)$ before tax per single person and 3 million ISK $(19,030 €)$ per couple. Additional income of 250,000 ISK (1586 €) is allowed for each dependent child. It is worth mentioning here that the income tax threshold in 2014 was $1,692,295$ ISK $(10,735 €)$ suggesting that the income criterion is set just above the income tax threshold, which seems to have been a benchmark for granting legal aid since the current legislation came in to force in 1992 (Gíslason 1994). ${ }^{6}$ In 2014, the average annual income for men in Iceland was 5,818,000 ISK (36,906 €), and for women 4,310,000 ISK $(27,340 €)$ (Statistics Iceland 2015a). ${ }^{7}$ This criterion, however, is not fixed and the regulation lists factors to be considered when deciding whether to grant legal aid even if the applicant's income is higher than the set amount.

The report commissioned by the Icelandic Bar Association mentioned above was critical of the inclusion of a fixed income criterion in the legal aid regulations. Based on a comparison with the other Nordic countries, the authors point out that the income criterion in Iceland is not indexlinked and that there is no mention of it being regularly evaluated. They are also critical of the fact that the income criterion is to be decided by the Minister for Judicial Affairs at any given time, as opposed to being fixed by law (Jónsson and Harðardóttir 2008).

The section B conditions for granting legal aid require that the outcome of the case should have great general significance, or be of great importance for the employment, social status, or other personal status of the applicant. The regulations further specify that when applications are evaluated on that basis, the Legal Aid Committee should consider whether the case would be thought important, and would matter significantly to a number of people, and whether the courts have previously settled a comparable or similar case. The regulations also specify that, when deciding if the outcome of the case would have a great impact on the employment, social status, or other personal status of the applicant, the Legal Aid Committee should assess how significant this impact would be. 


\section{Backlash During the Boom Years}

The law on legal aid remained more or less unchanged until 2005, when the eligibility criteria were tightened considerably by legislation and regulations. Since 1995, Iceland had been ruled by a right-wing coalition government that had been pursuing a neo-liberal economic agenda coupled with a statist approach, which involved selective deregulation and privatisation. ${ }^{8}$ The privatisation of the banks, coupled with lax financial regulations, resulted in the banks' unprecedented growth some of which was redistributed back into the country, resulting in an economic boom (Wade and Sigurgeirsdottir 2012). ${ }^{9}$ While state spending had increased during the boom years - though not as a percentage of GDP - and the rate of income tax percentage had been lowered, the tax burden on low and middle-income groups increased, due to the impairment of the tax threshold (Ólafsson 2007, 2010).

Against this political and economic backdrop, the Law on Civil Procedure no. 7/2005 was amended. The main changes to the general provisions on the eligibility criteria for legal aid were, first, further restrictions to legal aid in section A where, in addition to low income, the case now must be of such a nature that it would be considered appropriate that legal aid for it be financed by public funds. The second change was the cancelling of the conditions for legal aid laid down in section B, i.e. that the outcome of the case should have great general significance or be of great importance for the employment, social status, or other personal status of the applicant. ${ }^{10}$ In addition, the amendment gave clearer authorisation to the Minister for Judicial Affairs to provide more detailed guidance to the Legal Aid Committee on how to interpret the eligibility criteria for legal aid.

The aim of the amendment, as stated in the explanatory text accompanying the bill, was to clarify the rules on legal aid and to make the best use of funds. It is further stated that the section B provisions are very broad, and that it is not justifiable to use public funds to pay for people's lawsuits based on such a general provision. The bill was accompanied by a short annexe from the Ministry of Finance stating that the cost of legal aid would, in all likelihood, at least not continue to increase if the amendment was passed. Applications for legal aid had apparently 
increased from 315 in 1998 to over 500 in 2003 (General Committee of Alpingi, Majority Opinion).

While MPs from the ruling centre-right parties seemingly framed legal aid as something that should generally only be available based on low economic status, opposition MPs argued in defence of a wider provision. The minority in the General Committee, mostly comprising members of the Social Democratic Alliance, opposed the amendment on the grounds that it would, in the first place, limit the public's access to legal aid when they were seeking to defend their rights against the government, and state institutions; and in the second place, it would eliminate the possibility of legal aid in cases of great significance for the general public. The minority opinion also declared that the amendment went against the general public's sense of justice, and against legal aid developments in other democratic states.

The amendment was, however, passed and came into force on 11 February 2005. Subsequently, the Ministry for Judicial Affairs appointed a committee to examine the costs of legal aid in criminal and civil cases. ${ }^{11}$ In March 2006, the committee produced a report with suggestions on how to decrease spending on public cases and public legal assistance. The number of applicants granted legal aid had increased by $61 \%$ between 2000 and 2005 and legal aid costs had increased by 106\% during the same period. The cost of each legal aid case in Iceland in 2002 was the second highest out of 18 other European Countries. Only Denmark had higher costs. ${ }^{12}$ The committee highlighted custody cases and tort cases, which are the biggest categories and ones where costs had increased the most between 2000 and 2005. In respect to custody cases, the increase was attributable to legislative changes to the Act in Respect of Children (no. 76/2003) where the main rule of joint custody had been adopted; the ministry no longer had authority to make decisions on custody and only the courts could decide custody disputes. Another factor explaining rising costs was an increase in experts' assessment reports. To cut costs, the committee recommended mandatory mediation in custody cases, before a court case was initiated. ${ }^{13}$ Further cost-cutting measures recommended by the committee were the lowering of the income criteria for legal aid, and included more specific restrictions in the Legal Aid Committee's Regulations. As noted previously, public out-of-court legal 
aid is scarce in Iceland, while legal aid to pursue cases in court is available. This might also explain the relatively high cost of legal aid, as there is no financial incentive to resolve matters out of court (Magnússon 2005). The committee, however, did not recommend introducing legal aid for out-of-court cases as a means to cut costs in the long term. ${ }^{14}$

New regulations on the criteria for legal aid and the workings of the Legal Aid Committee (no. 45/2008) were set out in January 2008 fixing the annual pre-tax income criteria for legal aid at 1.6 million ISK $(17,445$ $€)$ per single person and 2.5 million ISK $(27,258 €)$ per couple. An additional 250,000 ISK (2726€) was allowed for each dependent child. ${ }^{15}$ In 2008, the income tax threshold for a single person was 1,191,004 ISK $(12,986 €)$. In that year, the average annual income for men in Iceland was 5,255,000 ISK $(57,295 €)$ and for women 3,738,000 ISK $(40,755 €)$.

Apart from those made by the minority in Alpingi's General Committee, the main objections to these changes came from lawyers and the Icelandic Bar Association. Two Supreme Court lawyers expressed outrage at the new law and the regulations it brought in, claiming that the income criterion was so low that it was incompatible with the law, and contrary to the will of Alpingi (Guðjónsson 2008). Here it is important to bear in mind that, although the benchmark for the income criterion has invariably been the tax threshold, its impairment, as noted earlier, can give an inaccurate impression of people's financial capacity. The Icelandic Bar Association criticised these changes in an open letter to the government, suggesting that, instead of cutting costs, it should increase the budget to ensure the rule of law (The Icelandic Bar Association 2007). The Icelandic Bar Association also commissioned a report on legal aid that concluded it was doubtful that the extensive limitations on legal aid introduced by the amendment to the law met the requirements needed to ensure access to justice and the right to a fair trial as stipulated in article 70 of the Icelandic Constitution and article 6 of the European Convention on Human Rights. It also noted that it was not clear why Alpingi decided that citizens in certain types of cases had a right to legal aid irrespective of their economic status - which raised questions regarding the equality principle. According to the authors, it would be simpler to have more extensive legal aid provision and thus ensure equality between citizens (Jónsson and Harðardóttir 2008). 
As noted at the beginning of this chapter, the restriction of access to legal aid, seemingly just to reduce costs, first by the 2005 legislation and subsequently by further legal aid regulations in January 2008, came at a time when the Icelandic economy was booming. The changes to legal aid are in line with the neo-liberal economic policy of the government according to which legal aid is viewed as a line in the state budget that needs to be kept in check, even if this means severely testing, if not breaching, the human rights principle of access to justice, enshrined in the constitution. At a time of considerable economic flexibility, a more measured approach could have developed a more comprehensive policy on legal aid. In the long term, introducing free out-of-court legal assistance, for example, might have decreased legal aid expenses overall.

\section{In the Eye of the Economic Storm}

After the economic collapse in October 2008, and the subsequent mass demonstrations against the government, in 2009, a new left-wing government was formed by the Social Democratic Alliance and the LeftGreen Movement: the first left-wing government since World War Two. The left-wing parties took the reins of government in a severe economic depression. However, as early as 2010 , the income criterion in the regulations was increased to its current level and in 2012, by an amendment to law no. 72/2012, the eligibility criteria for legal aid according to the first paragraph of Article 126 of the Law on Civil Procedure were again extended, with the reintroduction of section $\mathrm{B}$.

The main argument for reintroducing section B came from the Economic Affairs and Trade Committee (EATC) of the Icelandic Parliament, stating that legal aid should be available to those debtors who might have a reason to initiate court cases against financial institutions that, on the basis of a decision by The Icelandic Competition Authority no. 4/2012 on 9 March 2012, had been allowed a degree of cooperation in the effort to expedite the reconstruction of debts of individuals and companies. While the Minister for Judicial Affairs emphasised that the main purpose of legal aid should be to support those who could not afford to cover the costs of court cases, the EATC 
reiterated the importance of increasing the access of the general public to the courts, irrespective of their financial status. By that time, a cross-party bill reinstating section $B$ had been introduced in the three previous legislative assemblies. On these occasions, it had been emphasised that, firstly, the restrictions introduced in 2005 by the removal of section B severely limited the general public's ability to access justice in cases of considerable public or individual significance; and, secondly, they went against developments in legal aid in other democratic countries. The reintroduction of section B meant that legal aid became available in cases such as the following: claims for compensation for permanent invalidity, when invalidity is severe and the ability to earn a living is considerably reduced; cases concerning pension rights, employment rights or property rights; cases concerning compensation due to the loss of a provider; or cases to do with medical malpractice the right to privacy and other aspects of human rights.

However, in 2013, a centre-right government was voted back into office and currently a new government bill amending the law on legal aid has been prepared and was introduced to Alpingi in 2015-2016 but has, so far, not been enacted. In it, section B is removed once again, on the basis of the previous arguments, i.e., that it is not justifiable to pay for the lawsuits of individuals out of public funds under such a general provision, and that the main purpose of legal aid is to assist people of low economic status. The point is also made that disputes concerning the restructuring of loans have now mostly been resolved and therefore appropriate to re-evaluate the 2012 legal amendments. ${ }^{16}$

The question whether access to legal aid should be minimal or more extensive continues to be debate but without there being much by way of socio-legal research or a more comprehensive policy discussion on the general purposes and aims of legal aid for Icelandic society. On the face of it, the discussion seems to centre on the principle of access to justice and to divide along party lines, with the left wing mostly pushing for a more expansive understanding of access to justice, while the right wing mostly views legal aid as a budget concern. These divisions are thrown into relief when viewed against the backdrop of the extreme political and 
economic shifts that have characterised the politics and economy of Iceland in the last ten years. At the height of the economic boom the right-wing government restricted access to legal aid, while during the economic recession the left-wing government expanded it again. As we have seen, the return of a right-wing government has led to a bill reintroducing restrictions on access to legal aid.

\section{Legal Aid Applicants and Recipients}

Since the current legislation came into force in 1992, the majority of applications have concerned custody, compensation for physical injury, and cases where people have a legal right to state-funded legal aid (Gíslason 1994; Thoroddsen 2009; Ministry of the Interior 2014). While information on applications and legal aid grants has been published periodically, statistical information has varied according to the purpose of the publication, as can be seen in Table 6.1, which will be discussed in more detail below.

For the past 10 years, the Legal Aid Committee has processed between 438 and 599 applications a year and granted legal aid to between 292 and 397 applicants. The ratio of grants to applications has been $65-79 \%$ (Gíslason 1994; Ministry of Justice and Ecclesiastical Affairs 2006; Thoroddsen 2009; Ministry of the Interior 2013; Ministry of the Interior 2014). Statutory grants are those given to legal aid recipients who, by law, are entitled to state-funded legal aid. As already noted, such provisions can be found under various different laws. ${ }^{17}$ When interpreting the statistics certain factors should be borne in mind. First, it is important to note that, as previously discussed, access to legal aid was restricted by law in 2005 and then again by regulation in 2008. In 2010, access to legal aid was widened again through regulation and further expanded by law in 2012 . The year 2013 was the first whole year since 2005 when section B applications were submitted, and 30 applications were granted legal aid on that basis (Ministry of the Interior 2014). Secondly, statistical information for the years 2011-2013 was published in relation to the government's Gender Budgeting project, for the purposes of a gender analysis of applications and grants made. Therefore, information on grants made only exists if the applicants are individuals as indicated by the brackets in the Table 6.1. ${ }^{18}$ 


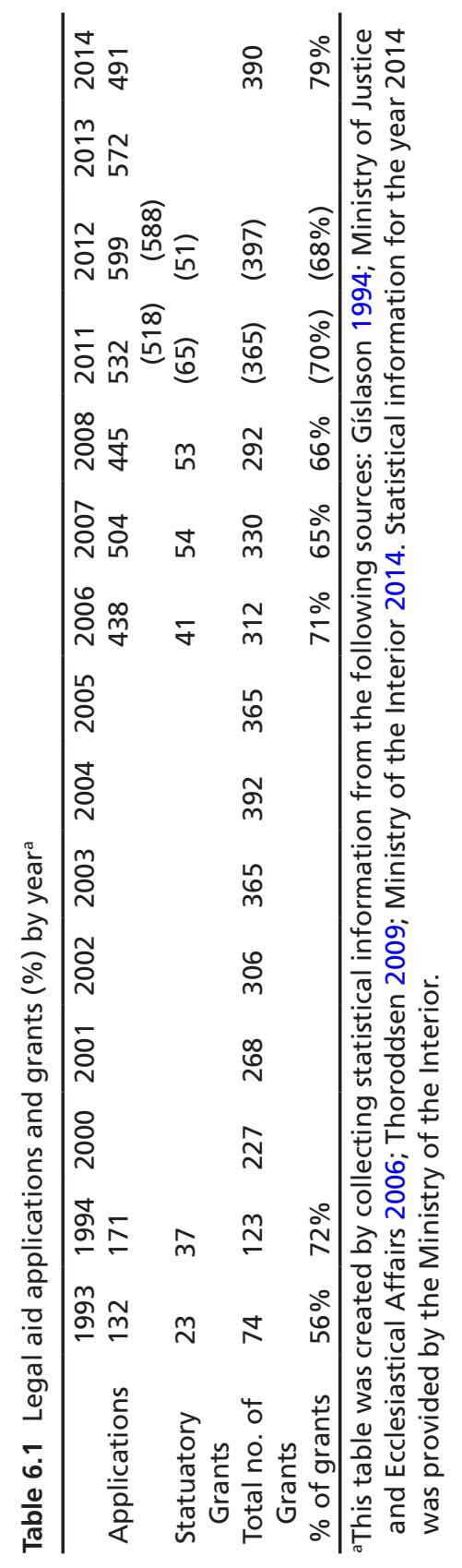




\section{Gender Analysis}

During 2011 and 2012, women and men on average submitted the same number of applications to the Legal Aid Committee: 51\% submissions were by women and $49 \%$ by men. Women's applications were more often successful $-76 \%$ of women's applications succeeded, as against $63 \%$ of men's. Women were more often granted legal aid than men on the basis of their low economic status, as stipulated in section A of the legislation. The reason for applying for legal aid is also partially gendered, as more women apply for legal aid in custody cases, while more men apply for legal aid in cases concerning compensation for physical injury. However, the amount granted to women is more often limited than that to men, as grants for custody cases are usually limited, while in cases of bodily injury, they are not. In 2011, the Legal Aid Committee received 17 applications from foreign nationals, ten women, and seven men. Of those 17 applications, 11 were awarded legal aid: seven women and four men (Ministry of the Interior 2013).

As mentioned above, on 1 January 2013 an amendment to the Act in Respect of Children made mediation in custody disputes mandatory before the initiation a court case. Applications concerning custody cases therefore decreased during that year, and those applications that were made were turned down. However, the number of other cases increased. As noted above, in 2008, the section B criteria were abolished but were reinstated in 2012. The first whole year when applications based on section B were submitted was 2013, and a total of 30 grants were awarded, divided equally between women and men (Ministry of the Interior 2014).

\section{Legal Expenses Insurance}

Legal expenses insurance (LEI) was introduced by one insurance company in Iceland in the late 1990s, after which the other main insurance companies started to provide similar policies. LEI is included in some home and family packages and the policy conditions are mostly similar. The main insurance companies typically offer four types of family insurance packages, of which only the most basic does not include LEI, which might suggest that low-income families are less likely to have 
cover. LEI does not generally cover out-of-court legal services, and the relatively long list of exemptions indicates that policy conditions are quite strict. ${ }^{19}$

\section{Access to Free Legal Counselling}

In Iceland, there is no general legislation that ensures that citizens have access to free legal counselling or out-of-court legal assistance. As previously mentioned, such provisions were included in two separate bills brought before Parliament in the 1980s, but neither of them came into force. Free legal counselling services are available through several members' organisations and voluntary organisations but free out-of-court legal assistance is rarely provided, the legal assistance given by unions being an important exception.

Women's organisations have offered women free legal assistance for a long time. The pioneer in providing free legal information and advice was Auður Auðuns (1911-1999), who was the first woman to graduate as a lawyer in Iceland, the first woman to become Mayor of Reykjavík, and the first to become a minister. In the period 1940-1960, Auður provided free legal aid through the Mothers' Support Committee (Mæðrastyrksnefnd), founded in 1928 by a number of women's organisations to support poor mothers (Rafnar 1981). These services are now provided by the Single Parents' Association. In 1984, Women's Counselling was founded during an active time for the women's movement in Iceland, which also resulted in the foundation of the Women's List, a feminist political party, the Women's Shelter and Stigamot, a counselling centre for survivors of rape and incest. At Women's Counselling, social workers and lawyers, including final year social work and law students, provide free counselling for women and now also for men. Women's Counselling is open two days a week for two hours (The Women's Counselling n.d.).

In terms of members' associations, The Single Parents' Association has provided free legal services to members since 1975 and those services are available on request during office hours (The Single Parents' Association n.d.). The Organisation of Disabled has offered free legal information to its members since 1975 and can pursue cases if they are considered likely to set a precedent for people with disabilities in general, or large numbers 
of people with disabilities (The Organisations of Disabled, n.d). Unions also offer their members free legal information and assistance in disputes between employee and employer. Union membership in Iceland was $86 \%$ in 2014 and has been at that level since at least 2003 (Statistics Iceland 2015b).

The Icelandic Bar Association has organised free legal information for the general public since 1993 through the Lögmannavaktin, which is now open once a week for an hour and a half (The Icelandic Bar Association, n.d.-b). Law student unions also provide free legal information to the general public. Orator, The Law Students' Association at the University of Iceland, has provided free legal information since 1980 . The assistance is provided by telephone once a week for two and a half hours (The Law Students' Association at the University of Iceland, n.d.). Some law firms also offer free legal information and pro bono services, especially in relation to compensation cases.

Free legal counselling for immigrants is provided by the Icelandic Human Rights Centre (ICEHR) because of an agreement between the Ministry of Welfare and the ICEHR. The assistance is provided twice a week for six hours at a time (The Icelandic Human Rights Centre, n.d.).

\section{Conclusion}

In recent times, discussions on legal aid in Iceland can be characterised along the lines of right-wing vs left-wing politics and in narrow legalistic terms. Those to the right of the political spectrum have generally advocated for a more restricted access to legal aid, to be solely granted on the basis of low economic status, while those to the left of the political spectrum advocate for a broader access to legal aid for cases that are deemed to be of great significance for individuals or larger groups. So in Iceland, recent discussions on legal aid have taken place in the relative absence of socio-legal research and without the aim of developing a comprehensive policy on the topic. It is, therefore, difficult to discern how legal aid is conceptualised, understood, and used in Iceland. However, when viewing the development of the legal and policy frameworks, they seem to combine, to a greater or lesser extent, an understanding of legal aid as a form of charity, as a right, and as an individual responsibility. 
In previous centuries, legal aid was understood mostly as charity, or support for the poor and needy. When the current law on public legal aid in civil cases came into force in 1992, access to the courts was understood as a right that should be available irrespective of economic status with the addition that cases of great public or individual significance should also be eligible for legal aid, although the latter criteria remain contested. However, given that there are no provisions for legal aid in the form of legal counselling or out-of-court legal assistance, and that such support is provided either by members' organisations or by the voluntary sector, albeit in some cases supported by public funds, it could be argued that legal aid has never fully been disassociated from charity.

While there is no official policy on the relationship between legal aid and LEI, legal aid applicants have to inform the Legal Aid Committee if they have such insurance, which implies that the applications of holders of such policies are rejected. However, given that such insurance is not mandatory, and that the policy conditions are strict, it cannot, on the face of it, be claimed that legal aid is conceptualised as an individual responsibility in Iceland, at least not yet. One could, though, argue that a very low income criterion for legal aid that has at times prevailed in Iceland, because the income criterion has not been firmly index-linked, does in effect give the signal that individuals need to make their own arrangements for legal aid through the purchase of insurance.

\section{Notes}

1. See for example article 54 of the Law on Public Procedure (no. 74/1974), and article 45 of the Law on Children (no. 9/1981).

2. Article 125, paragraph 2, states that the Minister shall appoint a committee of three lawyers - the Legal Aid Committee-for four years at a time to review and give recommendations on legal aid applications. One committee member is to be appointed based on recommendations from the Icelandic Bar Association and another on the basis of recommendation from the Icelandic Judges' Association. The third is appointed by the Minister.

3. Current regulation on the eligibility criteria for legal aid and the workings of the Legal Aid Committee is no. 45/2008 with amendments no. 1059/2010 and no. 616/2012. 
4. The amount in Icelandic Kronor is converted to Euro on the basis of the exchange rate on 1 January $2010(1$ ISK $=0.0056218074 €)$ and rounded up to the nearest hundred.

5. Such provisions can be found in articles in the following laws: law on criminal procedure (no. 88/2008); the Child Protection Act (no. 80/2002); Laws on unions and labour disputes (no. 80/1938); adoption law (no. 130/1999); laws on obtaining advisory opinions from the European Free Trade Association (EFTA) Court on the clarification of the Agreement on the European Economic Area (no. 21/1994); laws on the Alping ombudsman (no. 85/1997); and the Act in Respect of Children (no. 76/2003).

6. Information on the income tax threshold was obtained via email correspondence with the Internal Revenue, Tax Office Akureyri on 18 April 2016. The amount in Icelandic Kronor is converted to Euro based on the exchange rate on 1 January 2014 ( 1 ISK $=0.0063433743 €$ ) and rounded up to the nearest hundred. I refer to the year 2014 so as to be able to compare it with average annual income statistics from Statistics Iceland, which does not have comparable statistics for 2015.

7. The amount in Icelandic Kronor is converted to Euro based on the exchange rate on 1 January 2014 ( 1 ISK $=0.0063433743 €$ ) and rounded up to the nearest hundred. I refer to the year 2014, as Statistics Iceland does not have comparable statistics for 2015.

8. The Independence Party, a liberal conservative party seen as right-wing in Icelandic politics, and the Progressive Party, a centre-right liberal and agrarian party, were in government from 1995 to 2007.

9. Between 2005 and 2007 Iceland's GDP per capita was in line with Denmark's-19\% above the European Union average (Svennebye 2008).

10. While the amendment imposed eligibility restrictions on the general provisions for legal aid, an exception was made to allow access to legal aid for those challenging decisions made by the Committee on Uninhabited Areas (Óbyggðanefnd), a public administration committee charged with determining the boundaries of private land, public land, and upland ranges.

11. The committee was comprised of five specialists: three lawyers and two economists, from the Ministry for Judicial Affairs and the Ministry of Finance.

12. Here the Committee is referring to the following survey: European Commission for the Efficiency of Justice (CEPEJ) (2005).

13. Mandatory mediation in custody cases was later enacted by an amendment to the Act in Respect of Children that came in to force in 2013. 
14. The Committee also discussed cutting costs in public cases, and made recommendations on this, but that discussion is outside the scope of this article.

15. The amount in Icelandic Kronor is converted to Euro based on the exchange rate on 1 January 2008 ( 1 ISK $=0.0109030226 €$ ) and rounded up to the nearest hundred.

16. The bill further suggests that applications for legal aid should no longer be submitted to the minister responsible for judicial affairs but to a District Commissioner (sýslumaður) whose decision can be appealed to the Legal Aid Committee. The Legal Aid Committee will be appointed as before except that, instead of the Minister for Judicial Affairs appointing one of the members of the committee, the appointment should be on the basis of a recommendation from the Icelandic Human Rights Centre (ICEHR).

17. Such provisions can be found in articles on the following laws: the law on Criminal Procedure (no. 88/2008); the Child Protection Act (no. 80/2002); laws on Unions and Labour Disputes (no. 80/1938); Adoption Law (no. 130/1999); laws on obtaining advisory opinions from the EFTA Court on the clarification of the Agreement on the European Economic Area (no. 21/1994); laws on the Alping ombudsman (no. 85/1997); and the Act in Respect of Children (no. 76/2003).

18. Applications from other legal entities were submitted in cases where decisions made by the Committee on Uninhabited Areas (Óbyggðanefnd), a public administration committee charged with determining the boundaries of private land, public land, and upland ranges, were being challenged.

19. Information on LEI is based on correspondence with the main insurance companies, which include SJÓVÂ, Vátryggingafélag Íslands hf., Tryggingamiðstöðin, and Vörður.

\section{References}

Björnsson, Ó. (2005). Dæmdur málskostnaður. Sanngjarn eða sorglegur? Lögmannablaðið, 11(3).

European Commission for the Efficiency of Justice (CEPEJ). (2005). European Judicial Systems 2002. Council of Europe Publishing. Retrieved April 22, 2016, from https://wcd.coe.int/com.instranet.InstraServlet?command=com. instranet. CmdBlobGet $\&$ InstranetImage $=1150243 \&$ SecMode $=1 \&$ DocId $=1$ 009444\&Usage $=2$ 
Eydal, G. B. (1973). Lögfræðiaðstoð án endurgjalds. Tímarit lögfreðinga, 23(4), $10-21$.

Gíslason, A. (1994). Gjafsókn. Úlfjótur, 47(4), 429-446.

Guðjónsson, E. J. (2008, May 17). Prengt að réttinum til gjafsóknar. 24 Stundir, 92(4), 1.

Jónsson, J. (2005). Um málskostnaðarákvarðanir. Lögmannablaðið, 11(3).

Jónsson, A. P., \& Harðardóttir, H. E. (2008). Skýrsla um gjafsóknarmálefni. Retrieved April 22, 2016, from http://www.lmfi.is/urskurdarnefnd/urskur$\operatorname{dir} / \mathrm{nr} / 4099 /$

Magnússon, S. T. (2005). Aðgangur að dómstólum á sviði einkamála. Tímarit lögfraðinga, 55(2), 133.

Ministry of Justice and Ecclesiastical Affairs. (2006 March). Skýrsla nefndar um málskostnað i opinberum málum og opinbera réttaraðstoð. Dóms- og kirkjumálaráðuneytið. Retrieved April 22, 2016, from https://www.innanrikisraduneyti.is/media/Skyrslur/DKM_malskostnadur.pdf

Ministry of the Interior. (2013) Gjafsókn og önnur opinber réttaraðstoð. Áfangaskýrsla II. Retrieved April 22, 2016, from https://www.fjarmalaraduneyti.is/media/skjal/irr_afang_2013.pdf

Ministry of the Interior. (2014). Gjafsókn og önnur opinber réttaraðstoð. Lokaskýrsla. Retrieved April 22, 2016, from https://www.fjarmalaraduneyti. is/media/rit2014/lokaskyrsla,-IRR-2014.pdf

Ólafsson, S. (2007). Skattastefna Íslendinga. In Stjórnmál og stjórnsýsla, veftimarit, 3(2). Stofnun stjórnsýslufræða og stjórnmála við Háskóla Íslands.

Ólafsson, S. (2010). Pandist ríkið út á árunum fyrir hrun? Umfang útgjalda hins opinbera 1990 til 2009 og stærð velferðarríkisins árið 2007. Fréttabréf nr. 7/2010. Pjóðmálastofnun Háskóla Íslands.

Rafnar, I. P. (1981) Réttarhjálp án endurgjalds. In Auðarbók Auðuns, pp. 111-122. Sævarsson, J. A. (2005). Lögmenn og aðrir sérfræðingar. Lögmannablaðið, 11(3). Statistics Iceland. (2015a). Income by sex and age 1990-2014. Statistics Iceland. Retrieved April 22, 2016, from http://px.hagstofa.is/pxen/pxweb/en/ Samfelag/Samfelag__launogtekjur__4_tekjur__1_tekjur_skattframtol/ TEK01001.px/table/tableViewLayout $1 /$ ? rxid=8e92f24e-8471-49bca77b-345f5c8e $460 f$

Statistics Iceland. (2015b). Trade union membership 2003-2014. Statistics Iceland. Retrieved April 22, 2016, from http://px.hagstofa.is/pxen/pxweb/ en/Samfelag/Samfelag__vinnumarkadur__vinnumarkadur/VIN01007. px/?rxid=536f1855-c58f-42d8-ba40-bd6c6e58c27e

Svennebye, L. (2008). GDP per capita, consumption per capita and comparative price levels in Europe. Final results for 2005 and preliminary results for 
2006 and 2007. Eurostat, Statistics in focus 112/2008. Retrieved April 22, 2016, from http://ec.europa.eu/eurostat/documents/3433488/5584112/ KS-SF-08-112-EN.PDF/1525ad79-fd56-4e13-99fd-07d75cf2f832

The Icelandic Bar Association. (2007). Bréf LMFÍ til stjórnvalda: Útgjöld til réttaraðstoðar og málskostnaðar í opinberum málum. Lögmannablađið, 13(1), p. 6. The Icelandic Bar Association (n.d.-a). Lögmenn og pjónusta. The Icelandic Bar Association. Retrieved April 22, 2016, from http://www.lmfi.is/logmenn-ogthjonusta/hvad-kostar-thjonusta-logmanns/

The Icelandic Bar Association. (n.d.-b). Lögmannavaktin. Retrieved April 23, 2016, from http://www.lmfi.is/forsida/

The Icelandic Human Rights Centre. (n.d.). Activities. Retrived April 23, 2016, from http://www.humanrights.is/en/activities

The Law Students' Association at the University of Iceland (n.d.). Lögfraðiaðstoð

Orators. Retrieved April 23, 2016, from http://www.humanrights.is/en/activities The Organisations of Disabled. (n.d.). Félags- og lögfrađirádgjöf. Retrieved April 23, 2016, from http://www.obi.is/is/radgjof-og-thjonusta/felags-og-logfraediradgjof The Single Parents' Association. (n.d.). Nýttu pér rádgjöfina. Retrieved April 23, 2016, from www.fef.is

The Women's Counselling. (n.d.). Kvennarádgjöfin. Retrived April 23, 2016, from http://kvennaradgjofin.is/kvennradgjofin.html

Thoroddsen, Á. (2009). Fróðleikur um störf og afgreiðslur gjafsóknarnefndar. Lögmannablaðið, 15(1), 20.

Wade, R. H., \& Sigurgeirsdottir, S. (2012). Iceland's rise, fall, stabilisation and beyond. Cambridge Journal of Economics, 36, 127-144.

Open Access This chapter is distributed under the terms of the Creative Commons Attribution 4.0 International License (http://creativecommons.org/ licenses/by/4.0/), which permits use, duplication, adaptation, distribution, and reproduction in any medium or format, as long as you give appropriate credit to the original author(s) and the source, a link is provided to the Creative Commons license, and any changes made are indicated.

The images or other third party material in this book are included in the work's Creative Commons license, unless indicated otherwise in the credit line; if such material is not included in the work's Creative Commons license and the respective action is not permitted by statutory regulation, users will need to obtain permission from the license holder to duplicate, adapt or reproduce the material. 